\title{
Species abundance distributions: investigation of adaptation mechanisms of plant communities
}

\author{
Natalya Ivanova ${ }^{*}$, and Irina Petrova \\ Botanical Garden of the Ural Branch of the Russian Academy of Sciences, 620144 Yekaterinburg, \\ Russian Federation
}

\begin{abstract}
The adaptive capacity of ecosystems is a key to maintaining ecosystem functions and preserving biodiversity at all levels. The research was carried out in the western Southern Ural low-hill terrains (Russia). We analyzed distributions of above-ground biomass of herb layer species in the primary spruce, long-term secondary birch 20-35-year forests, stable-term secondary 20-year aspen forests. Species abundance distributions (SAD) analysis allowed us to study the species diversity and the species structure of communities, to understand the mechanism of adaptation of the plant community to disturbance and the role of species biodiversity in this process. It became clear that only with sufficient species diversity can SAD be maintained stable, and the adaptive potential and resistance of plant communities to external influences can be preserved. In General, the SAD analysis can be considered useful and informative for studying the adaptation of plant communities. In addition, it is universal and can be applied to any terrestrial and aquatic ecosystems. SAD can also help in designing artificial plant communities with increased resilience and high ecosystem functions.
\end{abstract}

\section{Introduction}

Global climate changes, repeatedly reinforced by human impact, become a trigger for local and global environmental crises that will inevitably affect the economic well-being and food security of the population in many countries $[1,2]$. The ability of natural ecosystems to adapt to changing conditions and maintain stability and ecosystem functions is becoming increasingly important $[1,3]$. Most studies focus on species, populational, physiological and genetic adaptation [4, 5], while only a few studies are devoted to identifying the features and mechanisms of ecosystem adaptation [6-9]. However, the adaptive capacity of ecosystems is a key to maintaining ecosystem functions and preserving biodiversity at all levels $[1,9]$.

Species abundance distributions (SAD) analysis (which is a fundamental pattern in ecology $[10,11])$ can be one of the methods for studying the adaptation of plant communities. SAD analysis allows you to identify differences in the organization of the plant community. SAD graphs are curves that are defined by many rare species and several dominants $[10,12,13]$. Analysis of these distributions allows inferences beyond those that

* Corresponding author: i.n.s@bk.ru 
flow from many simple diversity indices [10]. In addition, it provides a theoretical basis for the study of other environmental models. The strength of SAD is the ability to compare communities that differ in species composition and species richness on their basis [10].

The purpose of our research is to identify the features of maintaining the stability of SAD plant communities in forests of the Ural Mountains and the patterns of their transformation under the influence of such a large-scale impact as wood harvesting.

\section{Materials and methods}

The research was carried out in the western Southern Ural low-hill terrains located in the Chelyabinsk region between $54^{\circ} 33^{\prime}-54^{\circ} 40^{\prime} \mathrm{N}$ latitude and $57^{\circ} 48^{\prime}-57^{\circ} 55^{\prime}$ E longitude. It is part of the Atlantic-continental forest region of the temperate zone. The frost-free season does not exceed 120 days. Dark coniferous forests grow here. However, intensive timber harvesting has led to the spread of secondary birch and aspen forests. Therefore, this area is convenient for conducting research on forest dynamics. We studied primary 140-160-yearold dark coniferous forests and secondary birch and aspen forests, which ranged in age from 20-35 years. The size of the sample plot was 0.25 ha. In addition to the stand, the herb layer was studied in detail [14]. To determine the herb biomass, $251 \times 1 \mathrm{~m}$ sub-plots were laid on each sample plot. All plants on the sub-plots were cut and dried to a completely dry state at $105^{\circ} \mathrm{C}$. We used species biomass data to calculate SAD. Exponential and power functions were used for approximation. Rank models were built species abundance distributions analysis related to compliance with Gibbs (Motomura) and Pareto universal laws was carried out [10].

\section{Results and discussion}

We analyzed distributions of above-ground biomass of herb layer species in the primary spruce, long-term secondary birch 20-35-year forests, stable-term secondary 20-year aspen forests. It was found that the contribution to the total biomass of herb species differs sharply. Moreover, these differences are several orders of magnitude (Figures 1-3). At the same time, SAD is not random, but corresponds to certain theoretical laws. It has been found that species abundance distributions for the primary spruce forests is better approximated by the power function and corresponds to the Pareto theoretical law (Figure 1).

After logging and the formation of secondary birch and aspen forests, the total number of herb layer species remains fairly stable. This can be judged by the length of SAD (Figures 1-3). However, a number of species arranged in descending order of biomass looks fundamentally different. This is reflected in the captions to Figures 1-3. There is a change of the dominant and subdominant species. In other words, we observe a redistribution of the contribution of species to the total biomass of the herb layer. Species that dominate in primary forests are drastically reducing their biomass. Their place is taken by other species that had insignificant biomass in dark coniferous forests, but were more adapted to the changed conditions (early successional plant species that have the highest relative growth rates). This allowed preserving the biomass of the herb layer of the forest community and $\mathrm{SAD}$. And we were able to understand the mechanism of plant community adaptation to disturbance and the role of species diversity in this process. However, you should pay attention to the fact that the slope of the SAD graph does not remain stable. SAD analysis of herb layer of secondary forests revealed that logging leads not only to a change in the approximation function parameter (a decrease for all studied secondary forests in case of power function approximation), but also to a change in the abundance distribution law. All 
studied secondary forests are better described by the exponential function $\left(\mathrm{R}^{2}\right.$ greater than 0.91), which corresponds to the Gibbs-Motomura distribution (Figures 2-3). Power function approximation gives significantly worse results: $\mathrm{R}^{2}$ less than 0.83 . The Gibbs-Motomura distribution is thought to be realized under linear ecosystem species dependence on the resource, while the Pareto distribution is realized under logarithmic dependence.

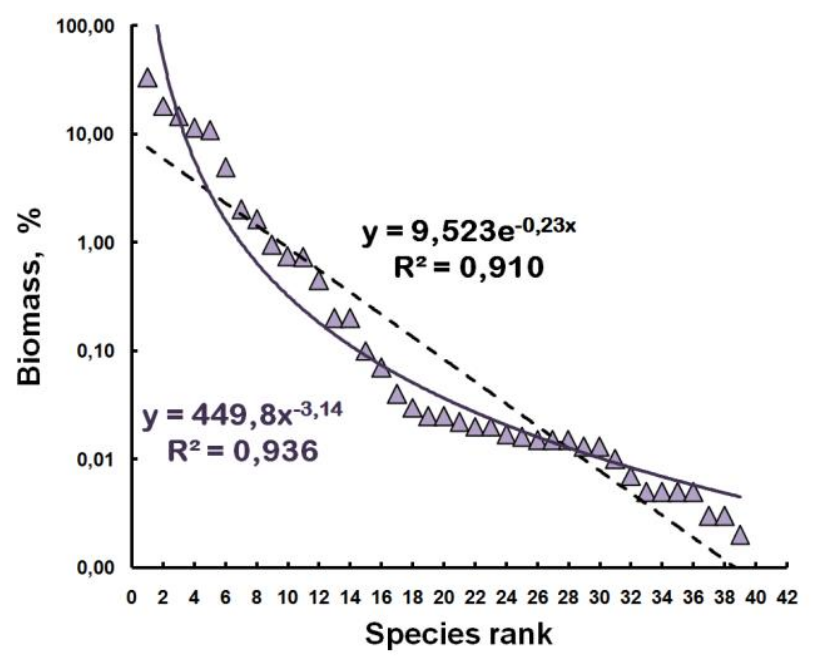

Fig. 1. Species abundance distributions of herb layer species in 140-years-old spruce forests in the Southern Ural Mountains: points - relative species biomass (\%); solid line - approximating power function; dotted line - approximating exponential function; species rank: 1 - Equisetum sylvaticum L., 2 - Athyrium filix-femina (L.) Roth, 3 - Calamagrostis arundinacea (L.) Roth, 4 - Lycopodium annotinum L., 5 - Lycopodium clavatum L., 6 - Dryopteris carthusiana (Vill.) H.P. Fuchs., 7 Luzula pilosa (L.) Willd., 8 - Oxalis acetosella L., 9 - Potentilla erecta (L.) Raeusch., 10 - Carex pilosa Scop., 11 - Stellaria holostea L., 12 - Maianthemum bifolium (L) F.W. Schmidt, 13 - Ajuga reptans L., 14 - Phegopteris connectilis (Michx.) Watt, 15 - Rubus saxatilis L., 16 - Bistorta officinalis Delarbre, 17 - Trientalis europaea L., 18 - Fragaria vesca L., 19 - Dryopteris filix-mas (L.) Schott, 20 - Viola epipsila Ledeb., 21 - Galeopsis bifida Boenn., 22 - Solidago virgaurea L., 23 - Agrostis tenuis Sibth., 24 - Dactylis glomerata L., 25 - Poa pratensis L., 26 - Carex rhisina Blytt. ex Lindbl., 27 - Cerastium pauciflorum Steven ex Ser., 28 - Stellaria bungeana Fenzl., 29 Ranunculus auricomus L., 30 - Ranunculus cassubicus L., 31 - Alchemilla L., 32 - Sanguisorba officinalis L., 33 - Lathyrus vernus (L.) Bernh., 34 - Viola canina L., 35 - Vaccinium myrtillus L., 36 - Scrophularia nodosa L., 37 - Veronica chamaedrys L., 38 - Veronica officinalis L., 39 - Succisa pratensis Moench.

The species abundance distributions method has the advantage that it reflects the species structure comprehensively. First, the SAD clearly shows the species richness that corresponds to the number of ranks. The greater the species richness, the more points there are in the figure. Second, the angle of inclination of a series of points indicates the rate of decline in the abundance of species in the ranked series. At the same time, the value of the parameter of the approximating function can act as a complex index characterizing the species structure of a forest. This criterion allows comparison between different SAD. Third, we can analyze for compliance with the theoretical laws of the result obtained by us. It can be assumed that greater compliance with the theoretical law corresponds to a more harmonious species structure and probably greater stability.

Our conclusion that species abundance distributions are not unchanged in the course of secondary successions is well consistent with literary data relevant to other regions $[10,12$, $13,15]$. 


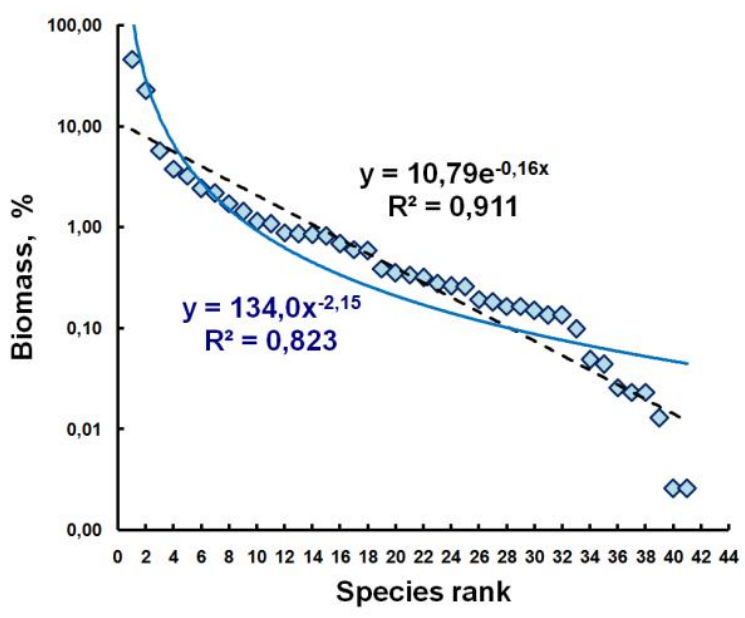

Fig. 2. Species abundance distributions of herb layer species in 35-years-old long-term secondary birch forests in the Southern Ural Mountains: points - relative species biomass (\%); solid line approximating power function; dotted line - approximating exponential function; species rank: 1 Carex pilosa Scop., 2 - Calamagrostis arundinacea (L.) Roth, 3 - Brachypodium pinnatum (L.) Beauv., 4 - Betonica officinalis L., 5 - Aegopodium podagraria L., 6 - Digitalis grandiflora Mill., 7 - Ajuga reptans L., 8 - Geum rivale L., 9 - Rubus saxatilis L., 10 - Galium boreale L., 11 - Angelica sylvestris L., 12 - Potentilla erecta (L.) Raeusch., 13 - Carex rhisina Blytt. ex Lindbl., 14 - Stellaria holostea L., 15 - Trollius europaeus L., 16 - Melica nutans L., 17 - Veronica chamaedrys L., 18 Hieracium umbellatum L., 19 - Lathyrus vernus (L.) Bernh., 20 - Cerastium pauciflorum Steven ex Ser., 21 - Succisa pratensis Moench, 22 - Pulmonaria obscura Dumort., 23 - Deschampsia caespitosa (L.) Beauv., 24 - Dactylis glomerata L., 25 - Pulmonaria dacica Simonk., 26 - Carex pallescens L., 27 - Juncus filiformis L., 28 - Maianthemum bifolium (L) F.W. Schmidt, 29 - Viola canina L., 30 - Cirsium heterophyllum (L.) Hill, 31 - Solidago virgaurea L., 32 - Luzula pilosa (L.) Willd., 33 - Fragaria vesca L., 34 - Ranunculus auricomus L., 35 - Trientalis europaea L., 36 Galium mollugo L., 37 - Agrostis tenuis Sibth., 38 - Bistorta officinalis Delarbre, 39 - Asarum europaeum L., 40 - Alchemilla L., 41 - Hypericum perforatum L.

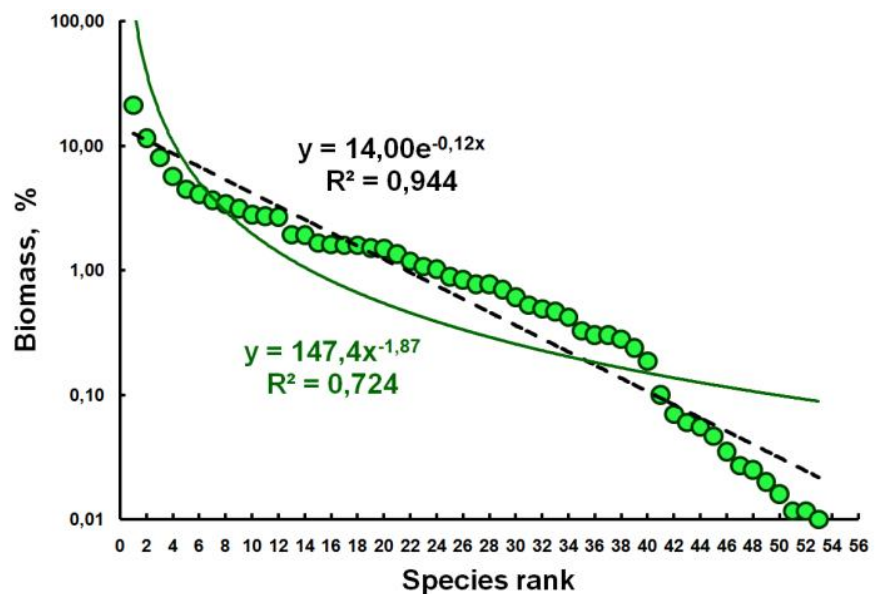

Fig. 3. Species abundance distributions of herb layer species in 20 -years-old stable-term secondary aspen forests in the Southern Ural Mountains: points - relative species biomass (\%); solid line approximating power function; dotted line - approximating exponential function; species rank: 1 Calamagrostis arundinacea (L.) Roth, 2 - Brachypodium pinnatum (L.) Beauv., 3 - Aconitum excelsum Rchb., 4 - Carex pilosa Scop., 5 - Pulmonaria obscura Dumort., 6 - Stachys sylvatica L., 7 
- Geum rivale L., 8 - Succisa pratensis Moench, 9 - Bistorta officinalis Delarbre, 10 - Calamagrostis epigeios (L.) Roth, 11- Cirsium heterophyllum (L.) Hill, 12 - Filipendula ulmaria (L.) Maxim., 13 Milium effusum L., 14 - Betonica officinalis L., 15 - Geranium sylvaticum L., 16 - Ajuga reptans L., 17 - Dactylis glomerata L., 18 - Rubus saxatilis L., 19 - Stellaria holostea L., 20 - Aegopodium podagraria L., 21 - Deschampsia caespitosa (L.) Beauv., 22 - Lathyrus gmelinii Fritsch, 23 Lathyrus vernus (L.) Bernh., 24 - Myosotis sylvatica Hoffm., 25 - Sanguisorba officinalis L., 26 Hieracium umbellatum L., 27-Alchemilla L., 28 - Dryopteris filix-mas (L.) Schott, 29 - Digitalis grandiflora Mill., 30 - Potentilla erecta (L.) Raeusch., 31 - Equisetum sylvaticum L., 32 Scrophularia nodosa L., 33 - Galium boreale L., 34 - Athyrium filix-femina (L.) Roth, 35 Cerastium pauciflorum Steven ex Ser., 36 - Melica nutans L., 37 - Paris quadrifolia L., 38 - Lilium pilosisculum (Freyn) Miscz. (L. martagon L.), 39 - Pulmonaria dacica Simonk., 40 - Asarum europaeum L., 41 - Trientalis europaea L., 42 - Luzula pilosa (L.) Willd., 43 - Primula macrocalyx Bunge, 44 - Viola canina L., 45 - Vicia sepium (L.) Moench, 46 - Melampyrum pratense L., 47 Stellaria graminea L., 48 - Origanum vulgare L., 49 - Hypericum perforatum L., 50 - Daphne mezereum L., 51 - Galium mollugo L., 52 - Viola epipsila Ledeb., 53 - Cicerbita macrophylla (Willd.) Wallr.

\section{Conclusions}

Thus, SAD analysis allowed us to study the species diversity and the species structure of communities, to understand the mechanism of adaptation of the plant community to disturbance and the role of species biodiversity in this process. It became clear that only with sufficient species diversity can SAD be maintained stable, and the adaptive potential and resistance of plant communities to external influences can be preserved. In General, the $\mathrm{SAD}$ analysis can be considered useful and informative for studying the adaptation of plant communities. In addition, it is universal and can be applied to any terrestrial and aquatic ecosystems. SAD can also help in designing artificial plant communities with increased resilience and high ecosystem functions.

\section{Acknowledgments}

The work was carried out within the framework of the state task of the Botanical Garden of the Ural branch of RAS

\section{References}

1. R. Maiti, H.G. Rodriguez, N.S. Ivanova, Autoecology and Ecophysiology of Woody Shrubs and Trees: Concepts and Applications, 352 (2016)

2. S. Vij, R., Biesbroek, A. Groot, K. Termeer, Environmental Science and Policy, 81, 77 (2018)

3. Md.A. Chowdhury, Md.Kh. Hasan, Md.R. Hasan, T.B. Younos, Heliyon 6(9), e05018 (2020)

4. K. Zavyalov, N. Ivanova, A. Potapenko, S. Ayan, CERNE, 25(4), 326 (2019)

5. Y.-C. Xu, Y.-L. Guo, Plant Commun., 1(6), 100103 (2020)

6. R.A. Lankau, Ecology, 94, 32 (2013)

7. N.S. Ivanova, E.S. Zolotova, Scientific Notes of Kazan University - Natural Sciences Series, 161(2), 293 (2019)

8. J.T. Bauer, L. Koziol, J.D. Bever, Oecologia 192, 735 (2020)

9. N.S. Ivanova, E.S. Zolotova, G. Li, Ecological Questions 32(2), 1 (2021) 
10. Th.J. Matthews, R.J. Whittaker, Journal of Applied Ecology, 52, 443 (2014)

11. L. Tan, P. Zhang, X. Zhao, C. Fan, C. Zhang, Y. Yan, K. Von Gadow, iForest 13, 482 (2020)

12. S.J. Alavi, R. Veiskarami, O. Esmailzadeh, K. Gadow, Forests 11, 701 (2020)

13. R.A.Fd. Lima, P.A. Condé, C. Banks-Leite, R.C. Campos, M.I.M. Hernández, R.R. Rodrigues, PLoS ONE, 15(9), e0238854 (2020)

14. N. Ivanova, Biology, Productivity and Bioenergy of Timber-Yielding Plants: An Experimental Technology, 121 (2017)

15. P.M. Villa, S.V. Martins, A.C. Rodrigues, N.V.H. Safar, M.A.C. Bonilla, A. Ali, Ecological Engineering, 135, 28 (2019) 